\title{
Effects of human impacts on diversity and distribution of chironomids (Diptera: Chironomidae) in prealpine springs
}

\author{
Valeria LENCIONI, ${ }^{*}$ Enrico MEZZANOTTE, ${ }^{2}$ Camilla SPAGNOL,,${ }^{2}$ Leonardo LATELLA ${ }^{2}$ \\ ${ }^{1}$ Department of Invertebrate Zoology and Hydrobiology, MUSE - Museo delle Scienze, Corso del Lavoro e della Scienza 3,38122 \\ Trento; ${ }^{2}$ Department of Zoology, Museo Civico di Storia Naturale of Verona, Lungadige Porta Vittoria 9, 37129 Verona, Italy \\ *Corresponding author: valeria.lencioni@muse.it
}

\begin{abstract}
Diversity and distribution of chironomid fauna (Diptera: Chironomidae) in 36 springs in the Italian Prealps (Veneto and Trentino NE-Italy, $46^{\circ} \mathrm{N}, 10-11^{\circ} \mathrm{E}$ ) was studied in relation to altitude, spring type and grade of disturbance. The springs were located between 62 and $1710 \mathrm{~m}$ asl of altitude, in three calcareous mountain areas (Mt. Baldo, Mts. Lessini and Mt. Pasubio). They differed in conservation status (natural, moderately and highly disturbed) and belonged to five hydromorphological types (rheocrene, limnocrene, rheohelocrene, rheolimnocrene, rheohygropetric). Each spring was surveyed once, between early summer and autumn, within $50 \mathrm{~m}$ of the spring's source (eucrenal). A total of 4198 chironomid larvae and pupae were sorted from 111 macroinvertebrate samples collected, belonging to five subfamilies (Tanypodinae, Diamesinae, Prodiamesinae, Orthocladiinae and Chironominae), 41 genera and 60 species/groups of species, and three juveniles taxa. As expected, Orthocladiinae accounted for a large part of specimens (88\%) and species (74\%), with Tvetenia calvescens/bavarica as the most frequent and abundant taxon, shared by pristine and disturbed springs and by all spring types. Most taxa were found in few sites, and frequencies declined gradually for most wider distributed species. A high number (74\%) of rare (=present in less than $10 \%$ of sites) taxa were found and from one to 23 taxa were identified per spring. Maximum richness occurred in moderately disturbed (Shannon- $\mathrm{H}=1.29 \pm 0.60$ ) springs, located at mediumhigh altitude (385-1266 m asl), according to the intermediate disturbance hypothesis. Even the evenness (Equitability-J) was higher as average in these springs. A Cluster Analysis run on Bray-Curtis similarity index highlighted a high similarity i) between the chironomid assemblages of moderately disturbed and natural springs (44 species in each spring group, with 29 species in common), and ii) between rheocrene and rheohelocrene types, thus the springs with the highest microhabitat heterogeneity. High individuality of springs was revealed, and new information about non-biting midges autecology provided. The utility of chironomids as bioindicators of water quality and ecological state of springs was confirmed, with some species e associated with high disturbance level (e.g., Polypedilum nubeculosum gr. to water intake works) and others with pristine conditions (e.g., Pseudodiamesa branickii).
\end{abstract}

Key words: Orthocladiinae; eucrenal; mosaic; tapped springs; spring types, Italian Prealps.

Contributions: EM, springs sampling; EM, CS, LL, collaboration on data processing; VL, statistical analyses performing, manuscript writing and revision; LL, study concept and design.

Received: March 2018. Accepted: April 2018.

This paper was presented at the $20^{\text {th }}$ International Symposium on Chironomidae, Trento, Italy, 2-8 July 2017. Session: Ecology and Biomonitoring.

\section{INTRODUCTION}

Spring-dwelling fauna is typically dominated by chironomids (Diptera: Chironomidae) in terms of both individual and species number (Lindegaard, 1995; Płóciennik et al., 2016). Chironomids are diverse and exhibit a wide variety of ecological preferences that provide potential in establishing reference conditions for bioassessment of freshwater ecosystems (Serra et al., 2018). However, due to taxonomic difficulties and poor knowledge of traits, chironomids are often neglected in biomonitoring programmes (Lencioni et al., 2012).

From the earliest studies on spring fauna that included chironomids (Bornhauser, 1912; Nadig, 1942), European literature on chironomid fauna in alpine springs and in spring-fed brooks increased from the end of the $90 \mathrm{~s}($ e.g., Orendt, 2000a; Füreder et al., 2001; Rossaro et al., 2006; von Fumetti et al., 2006; Lencioni et al., 2011; Robinson et al., 2016; von Fumetti and Blattner, 2017). These studies emphasised that springs and their biota are good tools for monitoring changes in groundwater quality caused by anthropogenic impact. Springs are in fact extremely sensitive to any type of disturbance because of their small dimensions (Orendt, 2000b; Cantonati et al., 2006). Springs have been seen as clean and pristine environments of high biological integrity, especially in mountain regions, at high altitude, but this condition is becoming more and more unusual. In the Alps, springs 
are frequently affected by water abstraction(that involves open or closed technical constructions for spring tapping and/or piping), forest management activities, agriculture, pasture sewage, trampling by cattle, road construction and drought due to global warming (Lencioni et al., 2012; Reiss et al., 2016). Nevertheless, no biotic indices have been developed to assess their ecological status. This is becoming an environmental emergency, in view of potential loss of ecosystem services provided by springs under global climate and environmental changes.

Although lists of chironomid species have been published on springs in Italian Prealps and Alps (e.g., Crema et al., 1996, Sambugar et al., 2006; Lencioni and Sartori, 2012), the influence of disturbance on biodiversity has been still little investigated. The aim of this work was to analyse distribution and diversity of chironomid fauna in thirty-six Pre-alpine springs in relation to altitude and their state of conservation (from pristine to highly disturbed), in a calcareous region particularly rich in springs (Zorzin et al., 2009).

\section{METHODS}

The springs

The thirty-six springs studied were located in three mountain areas ( 7 in Baldo Mt, 26 in Lessini Mts, 4 in Pasubio Mt) in the Italian Prealps (Veneto and Trentino NE-Italy, $46^{\circ} \mathrm{N}, 10-11^{\circ} \mathrm{E}$ ) (Fig. 1), within 62 and 1710 $\mathrm{m}$ a.s.1., on limestone substrate (Latella et al., 2012). The springs belonged to five hydromorphological types (17 rheocrenes-RHE, 7 limnocrenes-LIMNO, 5 rheohelocrenes-RHE-HEL, 6 rheolimnocrenes-RHELIMNO, 1 rheohygropetric-RHE-HYG) (Tab. 1). The level of disturbance was defined according to Lencioni et al. (2012), from 1=natural springs (14), $2=$ moderately disturbed springs (12) to $3=$ highly disturbed springs (10). Impacts were represented by open or closed technical constructions for water abstraction (spring tapping and/or piping),, modified bed (generally associated to water abstraction), polluted inputs by agriculture and grazing.

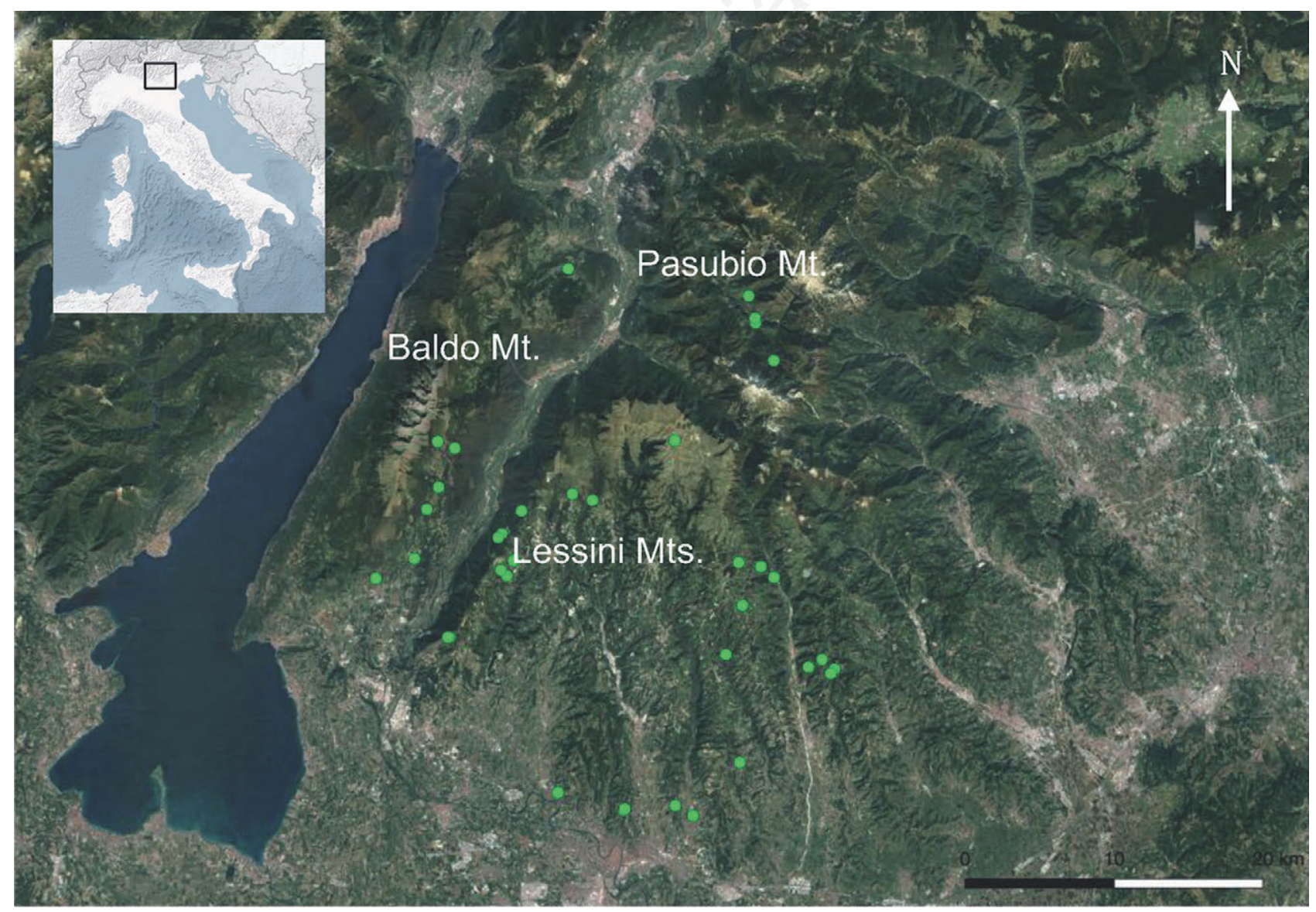

Fig. 1. Study area: thirty-six springs located in three mountain areas ( 7 in Baldo Mt, 26 in Lessini Mts, 4 in Pasubio Mt) in the Italian Prealps (Veneto and Trentino NE-Italy, $46^{\circ} \mathrm{N}, 10-11^{\circ} \mathrm{E}$ ), within 62 and $1710 \mathrm{~m}$ asl. 


\section{Chironomid sampling}

Each spring was surveyed once between early summer and early autumn 2001-2003 or 2007-2008. Chironomid larvae and pupae were collected in the eucrenal zone (=within $50 \mathrm{~m}$ of the spring's source) of each spring. One to three replicates were collected per spring by exploring different substrate typologies according to Lencioni et al. (2011). A pond net (100 $\mu \mathrm{m}$ mesh size) was used for 30 seconds in coarse ( $>0.2 \mathrm{~cm}$, from gravel to stones) and fine substrate $(<0.2 \mathrm{~cm}$, from sand to mud); submerged bryophytes were collected and washed in the laboratory to extract animals living within. The semi-quantitative samples

Tab. 1. List of thirty-seven springs, sorted by increasing altitude. Shannon Diversity is also reported for each spring.

\begin{tabular}{|c|c|c|c|c|c|c|c|}
\hline Spring name & Province & Mt Group & Altitude (m asl) & Spring type & $\begin{array}{c}\text { Conservation } \\
\text { state }\end{array}$ & $\begin{array}{c}\text { Year of } \\
\text { sampling }\end{array}$ & Shannon_H \\
\hline Squarà & Verona & Lessini & 62 & LIMNO & Highly disturbed & 2008 & 0.45 \\
\hline S. Cristina & Verona & Lessini & 75 & RHE & Highly disturbed & 2003 & 0.81 \\
\hline Balladoro & Verona & Lessini & 125 & RHE-LIMNO & Highly disturbed & 2008 & 1.35 \\
\hline Torricelle & Verona & Lessini & 220 & RHE-LIMNO & Moderately disturbed & 2008 & 1.68 \\
\hline Cava del Prete & Verona & Lessini & 230 & LIMNO & Moderately disturbed & 2001 & 1.60 \\
\hline Gaon & Verona & Baldo & 385 & RHE-LIMNO & Moderately disturbed & 2008 & 2.20 \\
\hline Pezza & Verona & Lessini & 428 & RHE-LIMNO & Highly disturbed & 2007 & 0.30 \\
\hline Prealba & Verona & Baldo & 445 & RHE-LIMNO & Moderately disturbed & 2008 & 1.40 \\
\hline Vajo Fontane & Verona & Lessini & 494 & RHE-LIMNO & Natural & 2003 & 0.86 \\
\hline Lodrone & Trento & Baldo & 517 & RHE & Natural & 2007 & 0.79 \\
\hline Biasetti & Verona & Lessini & 533 & RHE-HEL & Natural & 2008 & 2.20 \\
\hline Vajo del Croce & Verona & Lessini & 580 & LIMNO & Natural & 2008 & 1.41 \\
\hline Veraghi & Verona & Lessini & 622 & RHE & Moderately disturbed & 2007 & 0.00 \\
\hline Fonte Grande & Verona & Lessini & 637 & RHE-HYG & Moderately disturbed & 2008 & 1.33 \\
\hline La Ferrara & Verona & Lessini & 640 & LIMNO & Highly disturbed & 2007 & 1.49 \\
\hline Biuchele Speccheri & Trento & Pasubio & 676 & RHE & Natural & 2007 & 1.39 \\
\hline Boschi & Verona & Lessini & 690 & LIMNO & Highly disturbed & 2007 & 0.00 \\
\hline Cocher & Trento & Pasubio & 690 & RHE-HEL & Natural & 2007 & 1.96 \\
\hline Bertani & Verona & Lessini & 710 & RHE & Highly disturbed & 2001 & 0.00 \\
\hline Campopiano & Verona & Lessini & 710 & RHE & Natural & 2001 & 1.23 \\
\hline Val di Canova & Trento & Pasubio & 720 & RHE & Highly disturbed & 2007 & 0.29 \\
\hline Vaiara & Verona & Lessini & 760 & RHE-HEL & Natural & 2001 & 1.23 \\
\hline Gorgusello2 & Verona & Lessini & 772 & RHE & Moderately disturbed & 2001 & 1.05 \\
\hline Gorgusello1 & Verona & Lessini & 802 & RHE-LIMNO & Moderately disturbed & 2001 & 1.15 \\
\hline Monte Catini & Verona & Baldo & 840 & LIMNO & Highly disturbed & 2007 & 1.21 \\
\hline Covolo dell'acqua & Verona & Lessini & 860 & RHE & Natural & 2003 & 0.43 \\
\hline Fenil dei Coltri & Verona & Baldo & 894 & LIMNO & Highly disturbed & 2008 & 1.55 \\
\hline Druzzele & Verona & Lessini & 923 & RHE & Natural & 2003 & 1.59 \\
\hline Fondo Comperlon & Trento & Pasubio & 924 & RHE & Natural & 2007 & 1.48 \\
\hline Varalta & Verona & Lessini & 950 & RHE & Natural & 2008 & 1.30 \\
\hline Gauli & Verona & Lessini & 961 & RHE-HEL & Natural & 2003 & 1.13 \\
\hline Selvavecchia & Verona & Lessini & 1030 & RHE & Moderately disturbed & 2003 & 1.28 \\
\hline Grola & Verona & Lessini & 1129 & RHE & Moderately disturbed & 2003 & 1.92 \\
\hline Fontana della Teja & Verona & Baldo & 1215 & RHE & Moderately disturbed & 2008 & 0.42 \\
\hline Malga Lonza & Verona & Baldo & 1266 & RHE-HEL & Moderately disturbed & 2008 & 1.46 \\
\hline Fonte Chiarana & Verona & Lessini & 1710 & RHE & Natural & 2003 & 0.70 \\
\hline
\end{tabular}

RHE, rheocrene; LIMNO, limnocrene; RHE-LIMNO, rheolimnocrene; RHE-HEL, rheohelocrene; RHE-HYG, rheohygropetric. 
were preserved in $75 \%$ ethanol. Chironomids were mounted on slides and identified to species/groups of species according to Ferrarese and Rossaro (1981), Rossaro (1982), Ferrarese (1983), Wiederholm (1983, 1986), Nocentini (1985), Schmid (1993), Janecek (1998) and Lencioni et al. (2007). Morphological voucher specimens are deposited in the MUSE's entomological collection (INV017).

In each spring, water temperature, $\mathrm{pH}$ and conductivity were measured with a field multiprobe (Hydrolab 20; HACH Hydromet, Loveland, CO, USA). Discharge was measured using a graduated bucket, and measurements were repeated in different areas of the spring. Mean current velocity was measured with an acoustic doppler velocimeter (FlowTracker Handheld-ADV; SonTek, San Diego, CA, USA).

\section{Statistical analyses}

The mean abundance of each taxon per spring was considered, and relationships between frequency and abundance of taxa was investigated. Rare species, defined as present in less than $10 \%$ of springs (Lencioni et al. 2012), were included in the analysis, as recommended by Smith et al. (2001), resulting in a total of 63 taxa.

Species richness was calculated as sum of the number of species (count data $=\mathrm{S}$ ) and diversity by the ShannonWiener Index (H) (Shannon and Weaver, 1949), Dominance (D)=1-Simpson index and Equitability (J) (known also as Pielou's Evenness Index, calculated as Shannon diversity divided by the logarithm of number of taxa, according to Hammer et al., 2001). D ranges from 0 (all taxa are equally present) to 1 (one taxon dominates the community completely). J measures how evenly individuals are divided among the taxa present and assumes a value between 0 and 1 with 1 being complete evenness.

Significant differences in environmental features $(\mathrm{P}<0.05)$ between sites were estimated by Kruskal-Wallis test. The effect of the environmental variables (explanatory variables) on the chironomid species richness and diversity (response variables) was investigated by Regression Analysis using the least squares method (Gotelli and Hellison, 2004; Hammer et al., 2001). Two types of relationships were found, linear between altitude and water temperature (in the simple linear regression, the predictions of $\mathrm{Y}$ are plotted as a function of $\mathrm{X}$ forming a straight line: $\mathrm{y}=\mathrm{ax}+\mathrm{b}$ ) and quadratic (or $2 \mathrm{nd}$ order polynomial) between altitude and richness (in the quadratic regression, the predictions of $\mathrm{Y}$ are plotted as a function of a parabola: $\mathrm{y}=\mathrm{ax}^{2}+\mathrm{bx}+\mathrm{c}$ with $\mathrm{a}^{1} 0$ ).

Bray-Curtis similarities based on chironomid assemblages (abundance data were prior square root transformed) were calculated to compare springs grouped according to disturbance level $(1,2,3)$ and to hydromorphological type (the rheohygropetricRHE-HYG type was excluded from the analysis because it was represented by only one spring). The similarity matrices were used to run a Cluster Analysis. Analyses were performed using PAST 3.18 (Hammer et al., 2001).

\section{RESULTS}

Temperature and conductivity increased while discharge decreased with increasing level of disturbance $(\mathrm{P}<0.05)$

Tab. 2. Main physical and chemical features and biodiversity parameters of the thirty-six springs grouped according to their level of disturbance.

\begin{tabular}{|c|c|c|c|}
\hline & Highly disturbed (10) & Moderately disturbed (12) & Natural (14) \\
\hline Altitude (m asl) & $518 \pm 322$ & $729 \pm 370$ & $806 \pm 309$ \\
\hline Spring type (prevalent) & LIMNO & RHE-LIMNO & RHE, RHE-HEL \\
\hline Substrate & $\begin{array}{l}\text { Modified bed (cement); } \\
\text { fine sediment (organic debris); } \\
\text { scarce bryophytes }\end{array}$ & $\begin{array}{l}\text { Modified bed; coarse substrate; } \\
\text { some bryophytes }\end{array}$ & $\begin{array}{l}\text { Cobbles, gravel, leaves; } \\
\text { abundant bryophytes }\end{array}$ \\
\hline Discharge $\left(\mathrm{L} \mathrm{s}^{-1}\right)$ & $0.42 \pm 0.56$ & $0.55 \pm 0.58$ & $0.86 \pm 0.60$ \\
\hline Temperature $\left({ }^{\circ} \mathrm{C}\right)$ & $11.2 \pm 2.6$ & $9.7 \pm 2.1$ & $8.6 \pm 1.5$ \\
\hline $\mathrm{Ph}$ & $7.6 \pm 0.4$ & $7.6 \pm 0.2$ & $7.6 \pm 0.3$ \\
\hline Conductivity $\left(\mu \mathrm{s} \mathrm{cm}^{-2}\right)$ & $447 \pm 120$ & $390 \pm 134$ & $384 \pm 135$ \\
\hline Richness (S) & $5 \pm 3$ & $7 \pm 4$ & $7 \pm 2$ \\
\hline Shannon $(\mathrm{H})$ & $0.74 \pm 0.61$ & $1.29 \pm 0.60$ & $1.26 \pm 0.48$ \\
\hline Dominance (D) & $0.63 \pm 0.30$ & $0.40 \pm 0.24$ & $0.41 \pm 0.19$ \\
\hline Equitability (J) & $0.62 \pm 0.25$ & $0.77 \pm 0.13$ & $0.66 \pm 0.21$ \\
\hline
\end{tabular}

LIMNO, limnocrene; RHE-LIMNO, rheolimnocrene; RHE, rheocrene; RHE-HEL, rheohelocrene. 
(Tab. 2). Natural springs, represented mainly by the rheocrene and rheohelocrene type, were on average the coldest $\left(8.6 \pm 1.5^{\circ} \mathrm{C} ; \mathrm{P}=0.03\right)$ They were found at the highest altitudes (494-1710 $\mathrm{m}$ asl; $\mathrm{P}=0.04$ ) and featured the highest discharge $\left(0.86 \pm 0.60 \mathrm{~L} \mathrm{~s}^{-1}, \mathrm{P}=0.04\right)$ and the lowest conductivity $\left(384 \pm 135 \mu \mathrm{S} \mathrm{cm}^{-2}\right)$. Bryophytes were generally

A

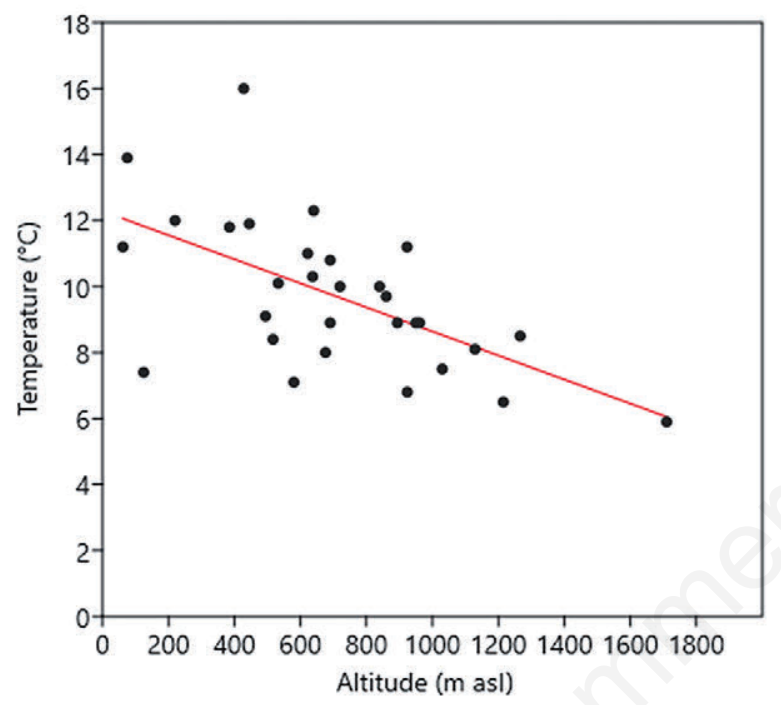

$\mathrm{B}$

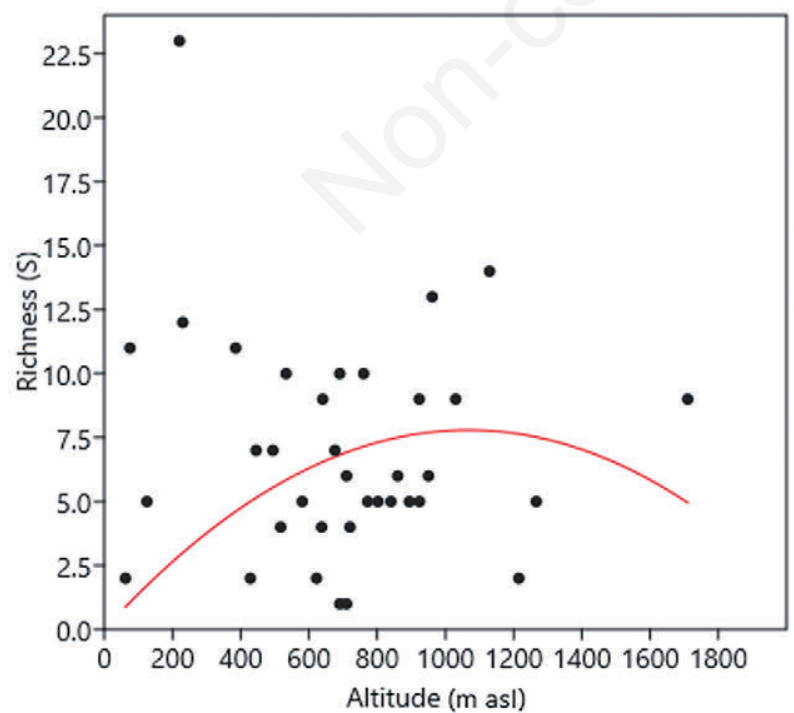

Fig. 2. A) Linear relationships between temperature $\left({ }^{\circ} \mathrm{C}\right)$ and altitude ( $\mathrm{m}$ asl) in the thirty-six springs (red line: $\mathrm{R}^{2}=0.351$, $\mathrm{P}=0.0005$ ). B) Local taxa richness of chironomids in the thirtysix springs as a function of Altitude. Red curve, quadratic fit $2^{\text {nd }}$ order polynomial model $\left(\mathrm{R}^{2}=0.053, \mathrm{P}=0.406\right)$. abundant (Tab. 2). Highly impacted springs, represented mainly by the limnocrene type, were warmer $\left(11.2 \pm 2.6^{\circ} \mathrm{C}\right)$, -flowing $\left(0.42 \pm 0.56 \mathrm{~L} \mathrm{~s}^{-1}\right)$, and all located below $894 \mathrm{~m}$ asl. Moderately impacted springs exhibited intermediate values of the main abiotic parameters (Tab. 2).

Considering the environmental features of the thirtysix springs, a clear relationship was found only between altitude and water temperature, i.e. water temperature decreasing with increasing altitude (Fig. $2 \mathrm{~A}, \mathrm{R}^{2}=0.353$, $\mathrm{P}=0.0005$ ).

A total of 111 macroinvertebrate samples were collected, in which 4,168 chironomid larvae and pupae were counted, belonging to five subfamilies (Tanypodinae, Diamesinae, Prodiamesinae, Orthocladiinae and Chironominae), 41 genera and 60 species/groups of species (Tab. S1, Tab. S2). Three other taxa were identified as juveniles: Pentaneurini juv., Orthocladiinae juv. and Tanytarsini juv., for a total of 63 taxa. Orthocladiinae accounted for a large part of specimens $(88 \%)$ and species (74\%), followed by Chironominae Tanytarsini $(6 \%$ of specimens and $9 \%$ of species), Tanypodinae (5\% of specimens and $12 \%$ of species). Chironominae Chironomini, Diamesinae and Prodiamesinae contributed to less than $1 \%$ of the specimens and $5 \%$ altogether of the species. In total, twenty-three crenophilous taxa were collected (Table S1) among which Krenopelopia binotata (Wiedemann, 1817), Trissopelopia longimana (Stæger, 1839), Chaetocladius dentiforceps gr., Chaetocladius piger gr., Corynoneura lobata Edwards, 1924, Synorthocladius semivirens Kieffer, 1909, Thienemannia gracilis Kieffer, 1909, Stempellinella flavidula (Edwards, 1929). Most species were frequent also in rhithral (e.g., Eukiefferiella minorfittkaui, Tvetenia calvescens/bavarica and Rheocricotopus effuses (Walker, 1856)) or lentic habitats (e.g. Heterotrissocladius marcidus (Walker, 1956), Zavrelimyia sp. and Macropelopia spp.).

Most taxa were found in few sites, and frequencies declined gradually for most widely distributed species. Many rare taxa were found $(46=74 \%)$ with one to 23 taxa per spring. Of these, 27 (44\%) occurred in only one spring (Fig. 3A). Among these all Diamesinae species, Pseudokiefferiella parva (Edwards, 1932), Pseudodiamesa branickii (Nowicki, 1873) and Prodiamesa olivacea (Meigen, 1818) were collected at $>920 \mathrm{~m}$ a.s.l., in rheocrene and rheohelocrene springs. Widespread species had relatively higher abundance than those with restricted distributions, with local abundance of taxa significantly increasing with the number of sites $\left(\mathrm{R}^{2}=0.5750 ; \mathrm{P}<0.0001\right)$ (Fig. 3B). Within exceptions, (species found in a low proportion of sites but abundant) S. semivirens accounted alone $21 \%$ of all specimens collected in the thirty-six springs. The most common taxa (=present in at least $40 \%$ of the sites) were: $T$. calvescens/bavarica, Parametriocnemus stylatus (Kieffer, 
1924), Micropsectra spp. and R. effusus (Fig. 3B). Among these, $T$. calvescens/bavarica was the most abundant, accounting $30 \%$ of the collected specimens.

The highest richness (S) occurred at intermediate altitudes (Fig. 2B; quadratic fit $2^{\text {nd }}$ order polynomial with $\mathrm{a}<, \mathrm{R}^{2}=0.053, \mathrm{P}=0.406$ ). It suggests that maximum richness is expected at intermediate altitude.

Maximum richness $(S=7 \pm 4$ ), diversity (Shannon-

A

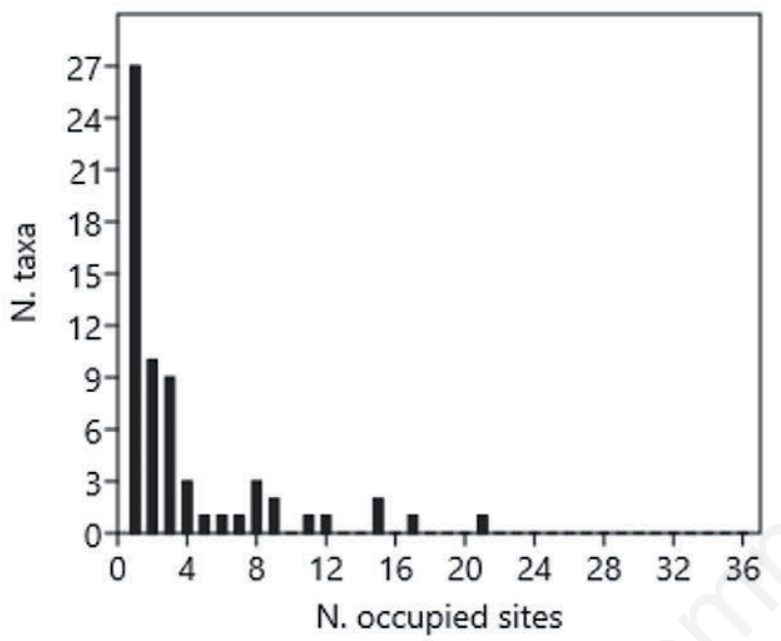

B

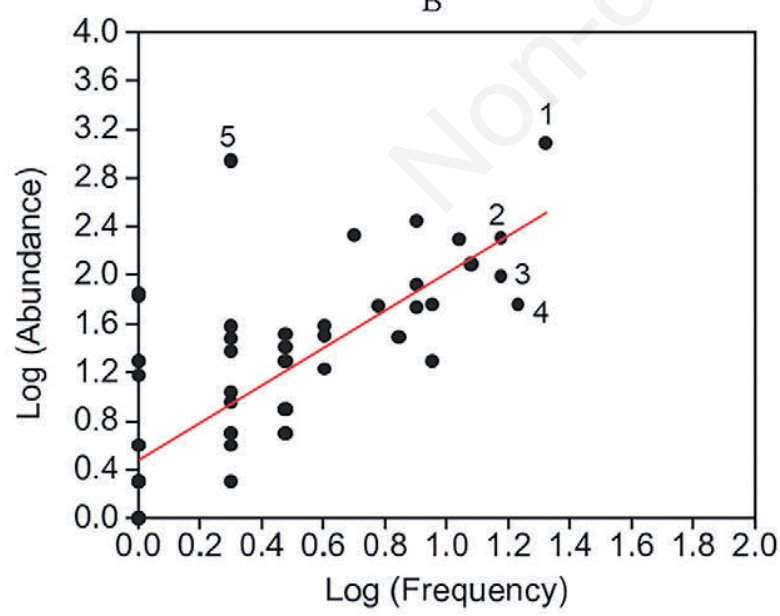

Fig. 3. A) Number of taxa in relation to number of sites occupied. B) Abundance-occupancy relationships $\left(\mathrm{R}^{2}=0.5750\right.$; $\mathrm{P}<0.0001)$. $1-4=$ taxa with a frequency $>40 \%$ : 1 . Tvetenia calvescens/bavarica, 2. Micropsectra spp., 3. Rheocricotopus effusus, 4. Parametriocnemus stylatus, 5. Synorthocladius semivirens: rare taxon (no. of occupied sites: 2) but abundant (accounting $21 \%$ of all specimens collected).
$\mathrm{H}=1.29 \pm 0.60$ ) and evenness (Equitability- $\mathrm{J}=0.77 \pm 0.13$ ) were estimated in moderately disturbed springs located at medium-high altitude (385-1266 m asl) (Tab. 2). Richness and diversity were not significantly correlated with any physical and chemical variables $(\mathrm{P}>0.05)$ but diversity decreased with increasing level of disturbance $\left(\mathrm{R}^{2}=0.112\right.$, $\mathrm{P}=0.046$ ). Highly impacted springs were characterized by lowest richness ( $\mathrm{S}=5 \pm 3$ ) and diversity $(\mathrm{H}=0.74 \pm 0.61)$, and
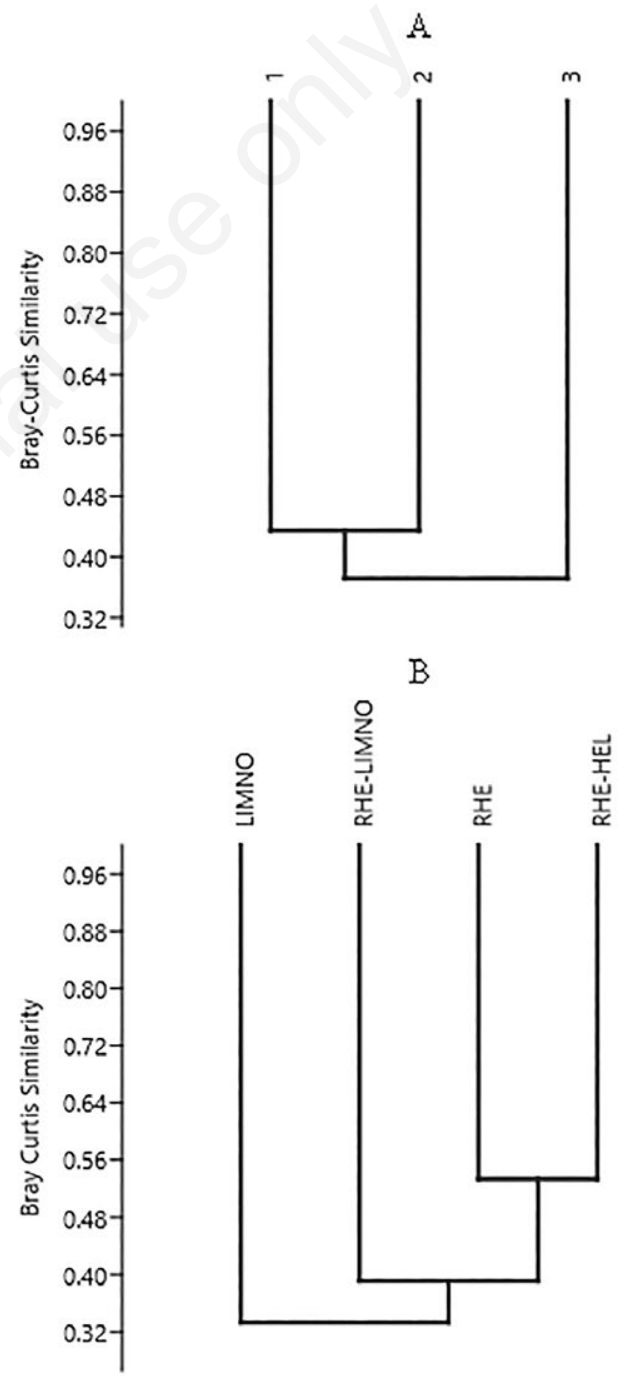

Fig. 4. Paired group (UPGMA) clustering based on the BrayCurtis similarities (ranging from $0=$ total dissimilarity, to $1=$ complete similarity). Clustering constrained to preserve row order. Based on species composition (63 taxa). A) 1, natural; 2 , moderately disturbed; 3, highly disturbed springs. B) 17 rheocrenes-RHE; 7 limnocrenes-LIMNO; 5 rheohelocrenesRHE-HEL, 6 rheolimnocrene-RHE-LIMNO. 
highest dominance $(\mathrm{D}=0.63 \pm 0.30)$ due to the dominance of two species out of the 24 identified, Paratrichocladius rufiventris/skirwithensis and Metriocnemus eurynotus gr. accounting respectively $39 \%$ and $18 \%$ of the specimens collected in this group of springs. The rheohelocrene springs were the richest in taxa $(\mathrm{S}=10 \pm 3)$, with the highest diversity $(\mathrm{H}=1.60 \pm 0.47)$ and the lowest dominance $(\mathrm{D}=0.30 \pm 0.16)$ (Tab. 3).

The Cluster Analysis highlighted a higher similarity between assemblages of moderately disturbed and natural springs (Fig. 4A). The index of similarity was 0.43 between groups 1 (=natural) and 2 (=moderately disturbed) and 0.31 between these two groups and group 3 (=highly disturbed). The three groups shared seventeen species. Group 1 and 2 contained forty-four species each, of which twenty-nine were in common, and included species, typically found in rheocrene, rheohelocrene and rheolimnocrene springs (e.g., R. effusus, Corynoneura lobata Edwards, 1924, Orthocladius (Euorthocladius) rivicola Kieffer, 1921). Highly disturbed springs (group 3 ), in agriculture areas and impacted by water abstraction, hosted species typical of euthrophic lentic habitats such as Polypedilum nubeculosum (Meigen, 1804).

Limnocrene springs were separated from the other spring type by the Cluster Analysis (Fig. 4B) with BrayCurtis similarity of 0.39 with RHE-LIMNO and 0.30 with RHE and RHE-HEL. The two types RHE and RHE-HEL were more similar to each other (Bray-Curtis Index $=0.53$ ), sharing twenty-two taxa. Species typical for lentic habitats found in LIMNO and in some RHE-LIMNO were Macropelopia spp., Natarsia sp., Paramerina sp., Metriocnemus fuscipes gr. In RHE and RHE-HEL rheophilous species were found (e.g. E. minor/fittkaui, T. calvescens/bavarica and R. effusus).

\section{DISCUSSION}

This study highlighted that the level of disturbance influences richness and diversity in springs. Anthropogenic pressure led to a decrease in both taxon richness and diversity, as expected (Orendt, 2000b; Płóciennik et al., 2016). The main disturbance was represented by water abstraction, associated with bed modification, building of fountains and artificial channels in cement, known to have the worst effect on chironomid biodiversity (Cantonati et al., 2006). Due to such modifications many cold rheocrene springs have been transformed in to warmer limnocrene springs, with the detriment of rheophilous and cold stenothermal species (mainly within Diamesinae and Orthocladiinae) and for the benefit of species typical for lentic habitats, even semi-aquatic such as Metriocnemus fuscipes gr., and Tanytarsini.

In accordance with the "intermediate disturbance hypothesis" (Connell, 1978), we found that maximum diversity occurred at intermediate regimes of disturbance in the moderately impacted springs. Barquin and Death (2004) found support for this hypothesis in their work in springs in northwestern Spain. In moderately disturbed springs, not only was Shannon diversity higher but also a higher equitability and lower dominance characterized the chironomid assemblages in respect to the other springs. The mean richness was comparable in the pristine springs (they shared more than $50 \%$ of species with the moderately disturbed springs), but they hosted communities with low evenness because most of them where dominated by only one or two taxa. Among these were $T$. calvescens/bavarica, that prevailed in many pristine springs and can be considered ubiquitous (overall

Tab. 3. Main physical and chemical features and biodiversity parameters of the thirty-six springs grouped according to their hydromorphological type.

\begin{tabular}{lccccc} 
& LIMNO & RHE & RHE-HEL & RHE-HYG & RHIE-LIMNO \\
Altitude $(\mathrm{m}$ asl) & $562 \pm 308$ & $819 \pm 359$ & $842 \pm 282$ & 637 & $419 \pm 236$ \\
\hline Mean level of disturbance & $2.6 \pm 0.8$ & $1.7 \pm 0.8$ & $1.2 \pm 0.4$ & 2.0 & $2.2 \pm 0.8$ \\
\hline Discharge $\left(\mathrm{L} \mathrm{s}^{-1}\right)$ & $0.48 \pm 0.99$ & $0.93 \pm 1.8$ & $0.56 \pm 0.40$ & 1.50 & $0.54 \pm 0.61$ \\
\hline Temperature $\left({ }^{\circ} \mathrm{C}\right)$ & $10.1 \pm 1.8$ & $9.1 \pm 2.3$ & $9.1 \pm 0.7$ & 10.3 & $11.3 \pm 3.3$ \\
\hline $\mathrm{pH}$ & $7.5 \pm 0.5$ & $7.6 \pm 0.3$ & $7.7 \pm 0.2$ & 7.6 & $7.6 \pm 0.3$ \\
\hline Conductivity $\left(\mu \mathrm{S} \mathrm{cm}^{-2}\right)$ & $409 \pm 113$ & $360 \pm 129$ & $437 \pm 136$ & 400 & $485 \pm 145$ \\
\hline Richness $(\mathrm{S})$ & $6 \pm 4$ & $7 \pm 4$ & $10 \pm 3$ & $1.60 \pm 0.47$ & $1.28 \pm 0.60$ \\
\hline Shannon $(\mathrm{H})$ & $1.10 \pm 0.62$ & $0.92 \pm 0.58$ & 1.60 & 0.28 & $0.40 \pm 0.24$ \\
\hline Dominance $(\mathrm{D})$ & $0.46 \pm 0.29$ & $0.57 \pm 0.26$ & $0.30 \pm 0.16$ & $0.75 \pm 0.20$ & 1.0 \\
\hline Equitability $(\mathrm{J})$ & $0.76 \pm 0.13$ & $0.59 \pm 0.21$ & $0.73 \pm 0.20$
\end{tabular}

LIMNO, limnocrenes (7); RHE, rheocrenes (17); RHE-HEL, rheohelocrenes (5); RHE-LIMNO, rheolimnocrenes (6); RHE-HYG, rheohygropetric (1). 
this taxon was the most frequent and the most abundant in the study sites) and $S$. semivirens, one of the most abundant but rare species, occurring in only two sites ("Covolo dell'acqua", rheocrene, $860 \mathrm{~m}$ asl, with coarse substrate; "Gauli", rheohelocrene, at $961 \mathrm{~m}$ asl, with medium size substrate and abundant leave mats). This finding and the high number of rare species $(74 \%)$ found in general, emphasized the highly individual nature of the springs, as stated for other alpine springs, e.g., by Staudacher and Füreder (2007) for Carinthian springs in Austria. This can be explained by the "mosaic" and multiple ecotonal structure (between aquatic-terrestrial (micro)habitats, groundwater-surface water, and crenalrhithral), of each spring to which faunal richness is related (Lindegaard, 1995; Bottazzi et al., 2011). In fact, where the "mosaic" is more complex, as in mixed types where more microhabitats are present (e.g., mosses, debris layers) (Cantonati et al., 2006), richness is expected to be higher, while limnocrene springs generally host fewer species (Smith and Wood, 2002; Smith et al., 2003; von Fumetti et al., 2006). Accordingly, a higher richness and diversity were estimated in the rheohelocrene and rheolimnocrene springs, as expected due to their highest microhabitat heterogeneity.

\section{CONCLUSIONS}

It is known that substrate lithology influences spring water chemistry, hydrologic regime, and substrate composition, affecting the faunal assemblages structure (van der Kamp, 1995). Having the same lithology, and all including more hydromorphological types and level of disturbance, no significant difference was found, on average, between the chemical features of the springs in the three mountain areas investigated. Furthermore, notwithstanding the isolation of the three areas that justify the occurrence of many endemics in the terrestrial entomofauna (Latella et al., 2012), no endemics were found within chironomids (Lencioni et al., 2011). The differences we detected are due to level of disturbance and spring type, and can be explained on the basis of chironomid autecology as reported in Eastern Alpine springs (Staudacher and Füreder, 2007) and in Dynaric Mountains springs (Płóciennik et al., 2016), highlighting chemical factors (such as conductivity) and altitude having weak influence on spring invertebrate communities because invertebrates react to a set of natural and altered conditions according to their autecology.

The utility of chironomids as bioindicators for water quality was confirmed, highlighting the fact that some species are associated with high disturbance levels (e.g., by water abstraction; $P$. nubeculosum) and others with pristine conditions ( $P$. branickii and $S$. semivirens).
Specifically, P. nubeculosum was found in tapped springs with modified bed, with high conductivity due to agricultural sewage inputs as expected (this species is frequent in meso-eutrophic lakes and in depositional zones in streams characterized by high amounts of nutrients; Nocentini, 1985). Also the autecology of $P$. branickii was confirmed, being a cold stenothermal species known from pristine springs and spring brooks rich in bryophytes, even at high altitudes (Lencioni et al., 2011). S. semivirens was described as a generalist taxon, a gatherer/collector and grazer living in both flowing and standing waters (Syrovátka and Brabec, 2008). Our results support its preference for coarse substrate and lotic habitats (it was absent in limnocrene springs).

Overall these results suggest that each spring can be considered a unique habitat, spatially restricted, and prudent and conservative land management should assume that all springs sheltering such unique faunal assemblages need protection.

\section{ACKNOWLEDGMENTS}

The research was carried out within three projects coordinated by Leonardo Latella and Roberto Zorzin (Museo Civico di Storia Naturale of Verona), co-funded by: (1) the Authority of the Adige River within the CESSPA project (Censimento e Studio delle Sorgenti e dei Pozzi del territorio alpino e prealpino di competenza dell'Autorità di Bacino del Fiume Adige; 2007-2009); (2) Museo Civico di Storia Naturale of Verona and (3) Speleological Commission of Verona (2001-2003). The authors thank Uberto Ferrarese for larvae identification from some springs, and Daniele Avesani, Nicoletta Verdari, Chiara Lampo, Roberto Zorzin, Gianni Sartori and Luca Toldo for field and laboratory assistance.

\section{REFERENCES}

Barquin J, Death G, 2004. Patterns in invertebrate diversity in streams and freshwater springs in northern Spain. Arch. Hydrobiol. 161:329-349.

Bornhauser K, 1912. [Die Tierwelt der Quellen in der Umgebung Basels].[Article in German]. Int. Rev. Ges. Hydrobiol. 5:1-90.

Bottazzi E, Bruno MC, Pieri V, Di Sabatino A, Silveri L, Carolli M, Rossetti G, 2011. Spatial and seasonal distribution of invertebrates in Northern Apennine rheocrene springs. J. Limnol. 70(s1):77-92.

Cantonati M, Gerecke R, Bertuzzi E, 2006. Springs of the Alps, sensitive ecosystems to environmental change: from biodiversity assessments to long-term studies. Hydrobiologia 562:59-96.

Connell JH, 1978. Diversity in tropical rain forests and coral reefs. Science 199:1302-1310. 
Crema S, Ferrarese U, Golo D, Modena P, Sambugar B, Gerecke $\mathrm{R}, 1996$. [Ricerche sulla fauna bentonica ed interstiziale di ambienti sorgentizi in area alpina e prealpina].[Article in Italian]. Centro di Ecologia Alpina, Report 8:1-104.

Ferrarese U, 1983. [Chironomidi, 3 (Diptera, Chironomidae: Tanypodinae)], p. 1-67. In: S. Ruffo (ed.), [Guide per il riconoscimento delle specie animali delle acque interne Italiane].[Book in Italian]. C.N.R. AQ/1/204 N. 26.

Ferrarese U, Rossaro B, 1981. [Chironomidi, 1 (Diptera, Chironomidae: generalità, Diamesinae, Prodiamesinae)], p. 1-97. In: S. Ruffo (ed.), [Guide per il riconoscimento delle specie animali delle acque interne Italiane].[Book in Italian]. C.N.R. AQ/1/129, N. 12.

Füreder L, Schütz C, Wallinger M, Burger R, 2001. Physicochemistry and aquatic insects of a glacier-fed and a spring-fed alpine stream. Freshwatater Biol. 46:1673-1690.

Gotelli NJ, Ellison AM, 2004. A primer of ecological statistics. Sinauer Associates, Sunderland: 492 pp.

Janecek BFR, 1998. [Diptera: Chironomidae (Zuckmücken) Larven. Fauna Aquatica Austriaca, Taxonomie und Oekologie aquatischer wirbelloser Organismen (Teil V)].[Book in German]. Universität für Bodenkultur, Abt. Hydrobiologie, Wien: 128 pp.

Hammer Ø, Harper DAT, Ryan PD, 2001. PAST: Paleontological statistics software package for education and data analysis. Palaeontologia Electronica 4:4. Accessed on: 9th January 2018.

Latella L, Verdari N, Gobbi M, 2012. Distribution of terrestrial cave dwelling arthropods in two close Prealpine Italian areas with different glacial histories. Zool. Stud. 51:1113-1121.

Lencioni V, Sartori G, 2012. [Diversità e distribuzione dei ditteri chironomidi in 22 sorgenti prealpine (Veneto)].[Article in Italian]. Boll. Mus. Civ. St. Nat. Verona Bot. Zool. 36:35-46.

Lencioni V, Marziali L, Rossaro B, 2011. Diversity and distribution of Chironomids (Diptera, Chironomidae) in alpine and pre-alpine springs (Northern Italy). J. Limnol.70(s1):106-121.

Lencioni V, Marziali L, Rossaro B, 2012. Chironomids as bioindicators of environmental quality in mountain springs. Freshw. Sci. 31:525-541.

Lencioni V, Marziali L, Rossaro B, 2007. [I Ditteri Chironomidi: morfologia, tassonomia, ecologia, fisiologia e zoogeografia]. [Book in Italian]. Quaderni Museo Tridentino Scienze Naturali 1:1- 172 .

Lindegaard C, 1995. Chironomidae of European cold springs and factors influencing their distribution. J. Kans. Entomol. Soc. 68:108-131.

Nadig A, 1942. [Hydrobiologische Untersuchungen in Quellen des Schweizerischen Nationalparkes im Engadin (unter besonderer Berücksichtigung der Insektenfauna). Ergebnisse der wissenschaftlichen Untersuchungen im Schweizerischen Nationalpark].[Article in German]. Aarau (N.F.) 1:270-432.

Nocentini A, 1985. [Chironomidi, 4 (Diptera, Chironomidae: Chironominae, larve)], p. 1-186. In: S. Ruffo (ed.), [Guide per il riconoscimento delle specie animali delle acque interne Italiane].[Book in Italian]. C.N.R. AQ/1/233, N. 29.

Orendt C, 2000a. Chironomids of small Alpine water bodies (springs, spring brooks, pools, small lakes) of the northern
Calcareous Alps. Spixiana 23:121-128.

Orendt C, 2000b. The chironomid communities of woodland springs and spring brooks, severely endangered and impacted ecosystems in a lowland region of eastern Germany (Diptera: Chironomidae). J. Insect Conserv. 4:79-91.

Płóciennik M, Dmitrović D, Pešić V, Gadawski P, 2016. Ecological patterns of Chironomidae assemblages in Dynaric karst springs. Knowl. Manag. Aquat. Ecosyst. 417:1-19.

Reiss M, Martin P, Gerecke R, von Fumetti S, 2016. Limnoecological characteristics and distribution patterns of spring habitats and invertebrates from the Lowlands to the Alps. Environ. Earth. Sci. 75:1033. Doi: 10.1007/s12665-0165818-8.

Robinson CT, Thompson C, Lods-Crozet B, Alther R, 2016. Chironomidae diversity in high elevation streams in the Swiss Alps. Fund. Appl. Limnol. - Arch. Hydrobiol. 188:201-213.

Rossaro B, 1982. [Chironomidi, 2 (Diptera, Chironomidae: Orthocladiinae)], p. 1-80. In: S. Ruffo (ed.), [Guide per il riconoscimento delle specie animali delle acque interne italiane Italiane].[Book in Italian]. C.N.R. AQ/1/171, N. 16.

Rossaro B, Lencioni V, Boggero A, Marziali L, 2006. Chironomids from Southern Alpine running waters: ecology, biogeography. In: A. Lami and A. Boggero (eds.), Ecology of high altitude aquatic systems in the Alps. Hydrobiologia 562:231-246.

Sambugar B, Dessì G, Sapelza A, Stenico A, Thaler A, Veneri A, 2006. [Fauna sorgentizia in Alto Adige].[Book in Italian]. Provincia Autonoma di Bolzano - Alto Adige: 372 pp.

Schmid PE, 1993. A key the larval Chironomidae and their instars from Austrian Danube region streams and rivers: with particular reference to a numerical taxonomic approach. Fed. Inst. for Water Quality, Wien: 514 pp.

Serra SRQ, Graça MAS, Dolédec S, Feio MJ, 2018. Discriminating permanent from temporary rivers with traits of chironomid genera. Ann. Limnol.-Int. J. Lim. 53:161-174.

Shannon CE, Weaver W, 1949. The mathematical theory of communication. Illinois University Press, Urbana.

Smith H, Wood PJ, 2002. Flow permanence and macroinvertebrate community variability in limestone spring systems. Hydrobiologia 487:45-48.

Smith H, Wood PJ, Gunn J, 2001. The macroinvertebrate communities of limestone springs in the Wye Valley, Derbyshire Peak District, UK. Cave Karst Sci. 28:67-78.

Smith H, Wood PJ, Gunn J, 2003. The influence of habitat structure and flow permanence on invertebrate communities in karst spring systems. Hydrobiologia 510:53-66.

Staudacher K, Füreder L, 2007. Habitat complexity and invertebrates in selected alpine springs (Schütt, Carinthia, Austria). Int. Rev. Hydrobiol. 92:465-479.

Syrovátka V, Brabec K, 2008. The response of chironomid larvae to hydraulic conditions: Synorthocladius semivirens (Diptera: Chironomidae) in two different rivers. Bol. Mus. Mun. Funchal Sup. 13:161-167.

Van der Kamp G, 1995. The hydrogeology of springs in relation to the biodiversity of spring fauna: A review. J. Kans. Entomol. Soc. 68(Suppl):4-17. 
von Fumetti S, Nagel P, Scheifhacken N, Baltes B, 2006. Factors governing macrozoobenthic assemblages in perennial springs in north-western Switzerland. Hydrobiologia 568:467-475.

von Fumetti S, Blattner L, 2017. Faunistic assemblages of natural springs in different areas in the Swiss National Park: a small-scale comparison. Hydrobiologia 793: 175-184.

Wiederholm T, 1983. Chironomidae of the Holoarctic region.
Keys and diagnoses. Part. 1. Larvae. Scandinavian Entomology, Lund: 457 pp.

Wiederholm T, 1986. Chironomidae of the Holarctic region. Keys and diagnoses. Part. 2. Pupae. Scandinavian Entomology, Lund: 482 pp.

Zorzin R, Pellegrini B, Annichini F, 2009. [Analisi della qualità dei principali acquiferi dell'altopiano carbonatico dei Monti Lessini Veronaesi].[Article in Italian]. Speleologia Veneta 6:29-59. 